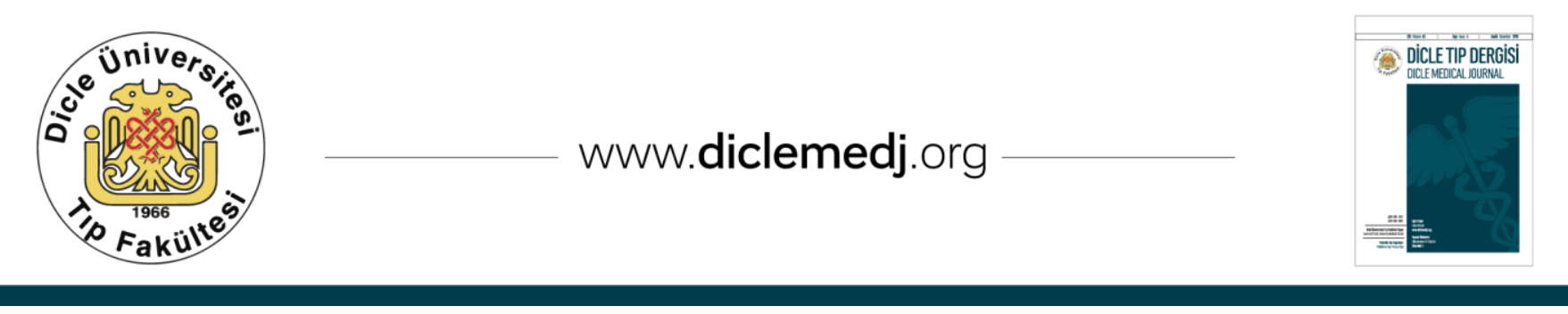

Özgün Araștırma / Original Article

\title{
Yaralanma Sonrası Ekstremitelerin Yumuşak Dokusunda Gözlenen Yabancı Cisimlere Cerrahi Yaklaşım
}

\author{
Abuzer Uludağ , Hacı Bayram Tosu², Necati Çiçek³ ${ }^{3}$ Mehmet Şirik \\ Öznur Uludağ5, Ramazan Atiç 6 \\ 1 Adlyaman Üniversitesi Tıp Fakültesi Ortopedi ve Travnatoloji AB Adlyaman, Türkiye ORCID: 0000-0003-3556-4327 \\ 2 Adlyaman Üniversitesi Tıp Fakültesi Ortopedi ve Travnatoloji AB Adlyaman, Türkiye ORCID: 0000-0001-6500-7260 \\ 3 Adıyaman Üniversitesi Tıp Fakültesi Ortopedi ve Travnatoloji AB Adlyaman, Türkiye ORCID: 0000-0002-6017-5836 \\ 4 Adlyaman Üniversitesi Tıp Fakültesi Radyoloji AB, Adlyaman, Türkiye ORCID: 0000-0002-5543-3634 \\ 5 Adlyaman Üniversitesi Tip Fakültesi Anesteziyoloji ve Reanimasyon AB, Adlyaman, Türkiye ORCID: 0000-0002-2341-9245 \\ 6 Dicle Üniversitesi Tıp Fakültesi Ortopedi Ve Travnatoloji AB, Diyarbakır, Türkiye ORCID: 0000-0002-7814-822X
}

Geliş: 26.11.2018; Revizyon: 12.02.2019; Kabul Tarihi: 04.03.2019

$\ddot{0} \mathbf{z}$

Giriş: Ekstremitelerde yabancı cisim yaralanmaları sık görülmelerine rağmen, tedavi yaklaşımları konusunda literatürde oldukça az bilgi bulunmaktadır. Bu çalışmada yumuşak dokuda yabancı cisim batması nedeniyle cerrahi tedavi uygulanan hastalarla ilgili epidemiyolojik bir çalışma amaçlanmıştır.

Yöntemler: 2012-2015 yılları arasında yumuşak dokuda yabancı cisim yaralanması nedeniyle cerrahi tedavi uygulanan 52 erkek ve 57 kadın hastadan oluşan toplam 109 hastanın hastane arşivinden hasta dosyalarına ve radyoloji pacs sisteminden radyolojik görüntülerine ulaşıldı. Hastaların demografik bilgileri, batan yabancı cisimlerin tipi ve battığı ortam, tetanoz ve antibiyotik profilaksisi yapılıp yapılmadığı, anestezi tipleri, yatış süreleri ve komplikasyonlar gibi bulgular tespit edildi.

Bulgular: Opere edilen 109 hastanın ortalama yaşı 28 (3-68) olarak tespit edildi. 62 (\%56.9) hastada yaralanma ev ortamında olurken, 47 (\%43.1) hastada ise ev dışı ortamda yabancı cisim battığı tespit edildi. Batan yabancı cisimler 43 hastada iğne, 28 hastada cam, 21 hastada metal cisim, 12 hastada ateşli silah yaralanması sonucu metal yabancı cisim ve 5 hastada ise tahta parçasına bağlı yaralanma tespit edildi. Yaralanmalar \%58,7 alt ekstremitede görülürken $\% 41,3$ üst ekstremitede görüldü. Yabancı cisim çıkartılması için cerrahi uygulanan $78(\% 71,6)$ hastaya lokal anestezi uygulanırken, diğer hastalara rejyonel veya genel anestezi uygulandı.

DOI: 10.5798/dicletip.539936

Yazışma Adresi / Correspondence: Abuzer Uludağ, Adıyaman Üniversitesi Tıp Fakültesi Ortopedi ve Travnatoloji AB, Adıyaman, Türkiye e-mail: uludagabuzer@gmail.com 
Lokal anestezi uygulanan hastalar aynı gün, genel ve rejyonel anestezi uygulanan hastalar ise cerrahi sonrası 1. günde taburcu edildi. Takiplerde hiçbir komplikasyon gözlenmedi.

Sonuç: Yabancı cisimler çoğunlukla ev ortamında oluşan yaralanmalardır. Direk radyografi yabancı cisimlerin büyük bir kısmında oldukça yararlıdır, fakat metal dışı yabancı cisimlerin belirlenmesinde ultrasonografi ve/veya manyetik rezonans incelemeden yararlanılmalıdır. Cerrahi girişim için anestezinin tipi hastanın yaşına ve yabancı cismin lokalizasyonuna göre seçilmelidir.

Anahtar kelimeler: Yumuşak doku, Yaralanma, Yabancı cisim, Ekstremite, Lokalizasyon.

\title{
Surgical approach to foreing bodies observed in the soft tissue of extremities after injury
}

\begin{abstract}
Objective: Although foreign body injuries are common in the extremities, there is little information about treatment approaches in the literature. In this study, an epidemiological study of patients who underwent surgical treatment for foreign body ingestion in soft tissue was aimed.

Methods: Between 2012 and 2015, a total of 109 patients (52 males and 57 females) who underwent surgical treatment for soft tissue foreign body injuries, received radiological images from the hospital archives and radiology pacs. Demographic data of the patients, type of foreign bodies sinking and submerged media, tetanus and antibiotic prophylaxis, anesthesia types, length of stay and complications were determined.
\end{abstract}

Results: The mean age of 109 patients was 28 (3-68) years. In 62 (56.9\%) patients, the injury occurred in the home environment and in $47(43.1 \%)$ patients, foreign body sank in the external environment. Sinking foreign bodies were detected by needle in 43 patients, glass in 28 patients, metal body in 21 patients, metal foreign body as a result of gunshot injury in 12 patients and injury due to wooden component in 5 patients. The injuries were seen in $58.7 \%$ of the lower extremities and $41.3 \%$ in the upper extremity. While local anesthesia was applied to 78 (71.6\%) patients who underwent surgery to remove foreign bodies, regional or general anesthesia was applied to the other patients. The patients who underwent local anesthesia were discharged on the same day, and general and regional anesthesia patients were discharged on the 1st postoperative day. No complications were observed during follow-up.

Conclusion: Foreign bodies are mostly injuries in the home environment. Direct radiography is very useful in most of the foreign bodies, but ultrasonography and / or magnetic resonance imaging should be used to identify non-metallic foreign bodies. The type of anesthesia for surgical intervention should be based on the age of the patient and the localization of the foreign body.

Keywords: Soft tissue, injury, foreign body, extremity, localization.

\section{GİRIŞ}

Aspirasyon ve yutma sonucu vücuda giren yumuşak doku yabancı cisimleri ile ilgili litaretürde oldukça fazla çalışma mevcutken, ekstremitelere yönelik yabancı cisim yaralanmaları konusunda kısıtlı sayıda çalışma bulunmaktadır. Acil servislere sık başvuru nedenlerinden olan yabancı cisim batmaları hakkında literatürde insidans, tanı ve tedavi yaklaşımı ile ilgili yeterli sayıda bilgi bulunmamaktadır. $\mathrm{Bu}$ çalışma da yumuşak dokuda gözlenen yabancı cisimler nedeniyle cerrahi uygulanan hastaların analizi yapılarak, epidemiyolojisi, tedavi yaklaşımlarının belirlenmesi amaçlanmıştır.

\section{YÖNTEMLER}

2012-2015 yılları arasında acil servise ya da polikliniğimize başvuru neticesinde yumuşak dokuda yabancl cisim tespit edilen ve bu nedenle cerrahi olarak yabancı cisim çıkartılan 141 hasta çalışmaya dahil edildi. Üniversitemiz lokal etik kurulundan (2015/05-3) sayı numarası ile onay alındı. 
Dosyasında veri eksikliği ya da radyolojik görüntü eksikliği olan 32 hasta çalışma dışı bırakıldı. Dahil edilme kriterlerini karşılayan 109 hasta (E/K: 52/57) retrospektif olarak incelendi. Hastaların yaş, cinsiyet, yaralanmanın olduğu ekstremite, yabancı cisim tipi, lokalizasyonu, cerrahi öncesi ve sonrası ilaç kullanımı, operasyon yapılan anestezi şekli ile birlikte hastanede kalış süreleri kaydedildi. Hastalara yabancı cismin tespiti ve yerleşimi için pacs sistemindeki direkt radyografiler ve hastane arşiv dosyaları tek hekim tarafından incelendi. Hastaların demografik bilgileri, tetanoz ve antibiyotik profilaksisi yapılıp yapılmadığı, anestezi tipleri, yatış süreleri, batan yabancı cisimlerin tipleri, yabancı cismin battığı ortam ve komplikasyonlar tespit edildi.

Tablo I. Yumuşak dokuda gözlenen yabancı cisimlerinin genel dağılımı.

\begin{tabular}{|l|l|l|}
\hline Hasta Sayısı & 109 & \\
\hline Yaş & $28(3-68)$ & \\
\hline Cinsiyet & Kadın & $57(\% 52,3)$ \\
\hline Tutulan Taraf & Erkek & $52(\% 47,7)$ \\
\hline Kaza ortamı & Sağ & $53(\% 48,6)$ \\
\hline & Sol & $56(\% 51,3)$ \\
\hline Yabancı cisim dağılımı & Ev & $62(\% 56,9)$ \\
\hline & Ev dişı & $47(\% 43,1)$ \\
\hline & Metal iğne & $43(\% 39,5)$ \\
\hline Cam & $28(\% 25,7)$ \\
\hline Anestezi şekli Silah & $12(\% 11)$ \\
\hline & Tahta & $5(\% 4,6)$ \\
\hline & Lokal & $78(\% 71,6)$ \\
\hline & Genel & $19(\% 17,4)$ \\
\hline & Rejyonel & $12(\% 11)$ \\
\hline
\end{tabular}

\section{BULGULAR}

Ortalama yaşları 28 (3-68) olan toplam 109 hasta (E/K: 52/57) çalışmaya alındı. Hastaların 62 'sinde $(\% 56,9)$ yaralanmaların ev ortamında olduğu görüldü. Tüm hastalar direkt anterior- posterior ve lateral radyografi ile değerlendirildi. Sadece 1 hasta da ultrasonografi (USG) yapıldığı görüldü. Hastaların 43'ünde $(\% 39,5)$ iğne batması 28 'inde $(\% 25,7)$ cam batmass, 21'inde $(\% 19,2)$ metal batması,12'sinde (\%11) ateşli silah yaralanması sonucu metal yabancı cisim ve 5 'inde $(\% 4,6)$ ise tahta parçası batması sonrası yumuşak doku yabancı cismi gözlendi (Tablo I) Şekil (1-3).
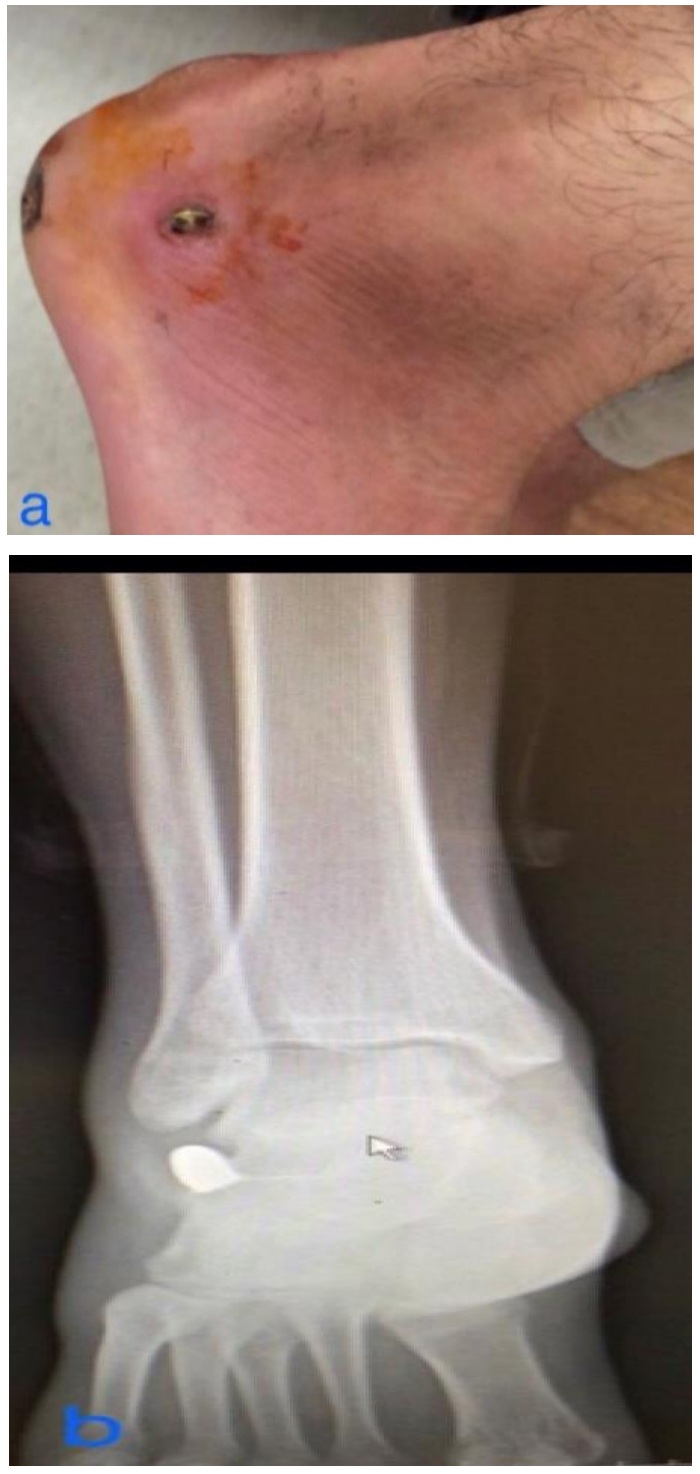

Şekil 1. Yüzeyel lokalizasyonda mermi çekirdeğinin görünümü: a) Klinik görünüm, b) Radyografik görünüm. 


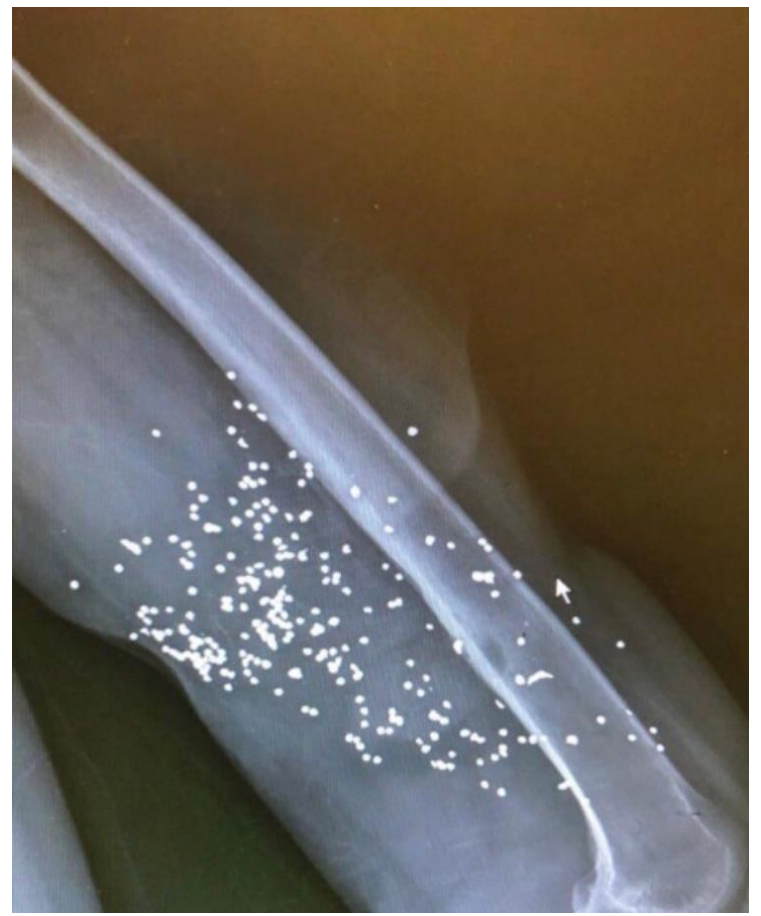

Şekil 2. Çok sayıda av tüfeğine bağlı ateşli silah yaralanmasına bağlı metal saçma mermi parçaları.

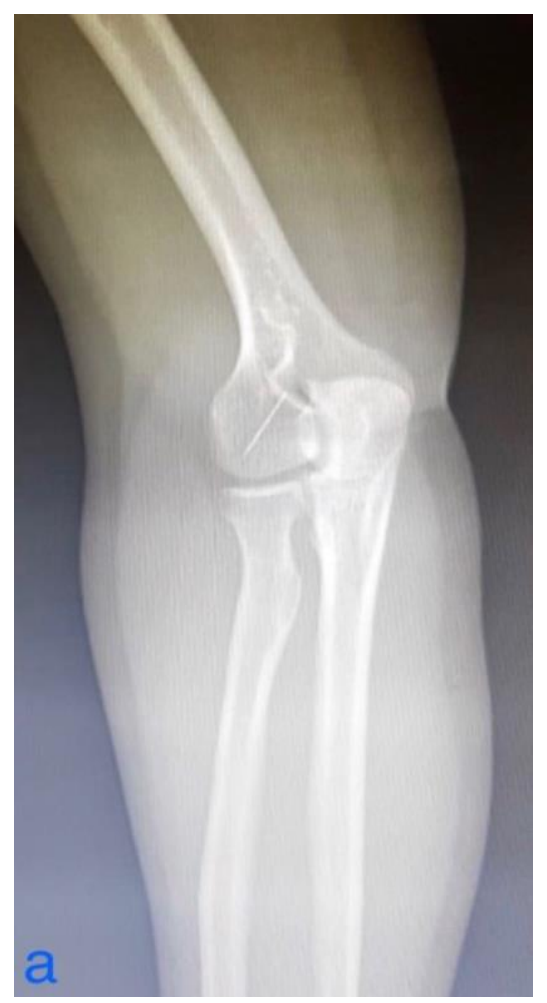

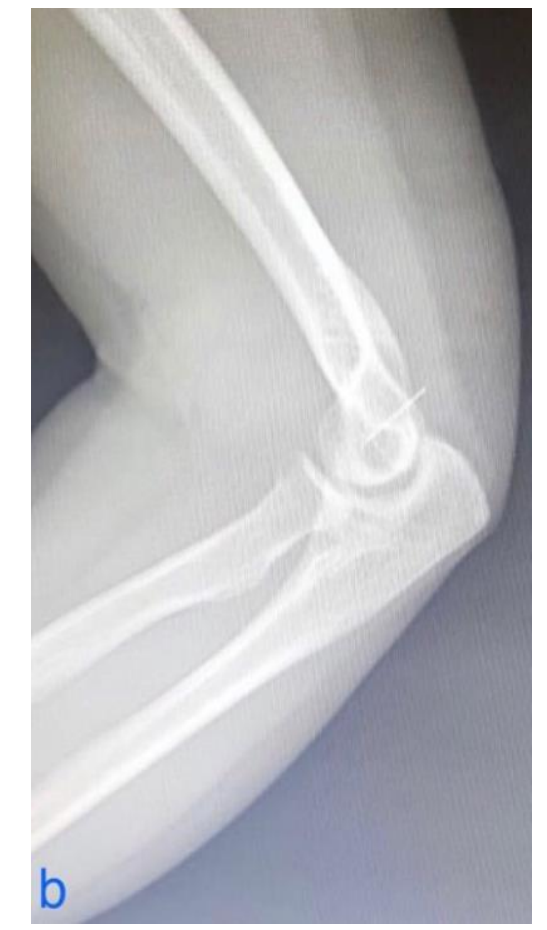
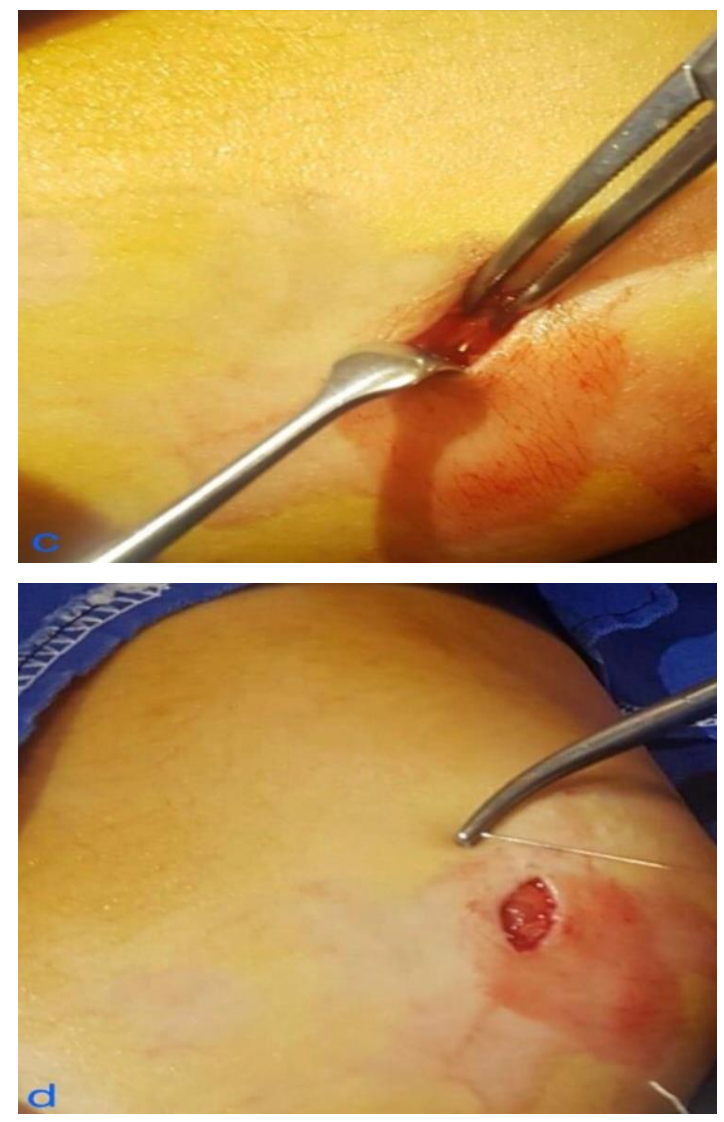

Şekil 3. Dirsek bölgesinde iğne batması şeklinde yabancı cisim: a) Anterior-posterior radyografik görünüm, b) Lateral radyografik görünüm, c) Yumuşak doku içinde yabancı cisim, d) Çıkartılan yabanc1 cisim. 
Hastaların 19'unda sağ, 30'unda sol üst ekstremite olmak üzere toplam 49 hastanın üst ekstremitesinde yabancı cisim yaralanması gözlendi. Bu yaralanmaların 43 tanesi el bileği seviyesinin altında olurken 6 hastada ise kol ve önkol seviyesinde yabancı cisim yaralanması gözlendi (Tablo II).

Tablo II. Üst ekstremite yumuşak dokuda gözlenen yabancı cisimlerin dağılımı.

\begin{tabular}{|c|c|c|}
\hline Hasta Sayısı & 45 & \\
\hline Yaş & $28.7(8-52)$ & \\
\hline \multirow{2}{*}{ Cinsiyet } & Kadın & $22(\% 48,9)$ \\
\hline & Erkek & $23(\% 51,1)$ \\
\hline \multirow[t]{2}{*}{ Taraf } & Sağ & $19(\% 42,2)$ \\
\hline & Sol & $26(57,8)$ \\
\hline \multirow{2}{*}{ Seviye } & El bilek üstü & $4(\% 8,9)$ \\
\hline & El bilek altı & $41(\% 91,1)$ \\
\hline \multirow{5}{*}{ Yabancı cimin oranı } & Metal iğne & $6(\% 13,3)$ \\
\hline & Cam & $21(\% 46,7)$ \\
\hline & Metal & $11(\% 24,4)$ \\
\hline & Ateşli Silah & $4(\% 8,9)$ \\
\hline & Tahta & $3(\% 6,7)$ \\
\hline \multirow{3}{*}{ Anestezi şekli } & Lokal & $36(\% 80)$ \\
\hline & Genel & $5(\% 11,1)$ \\
\hline & Rejyonel & $4(\% 8,9)$ \\
\hline
\end{tabular}

Alt ekstremitede gözlenen yabancı cisim yaralanmaları ise; 33 hastada sağ, 27 hastada ise sol alt ekstremitede olmak üzere toplam 60 hastada yumuşak doku yabancl cisim yaralanması gözlendi. Bu yaralanmaların 15'i ayak bileği üzerinde iken, 45 hasta da ise ayak bileği seviyesinin altında yabancı cisim yaralanması mevcuttu (Tablo III).

Tüm hastalara ameliyathane ortamında müdahale edildi. 78 hastaya $(\% 71,6)$ lokal anestezi, 19 hastaya $(\% 17,4)$ genel anestezi, 12 hastaya ise $(\% 11)$ ise rejyonel anestezi uygulandı. Genel anestezi yapılan 12 hastanın ortalama yaşı 6,6 (3-14) idi.

Tablo III. Alt ekstremite yumuşak dokuda gözlenen yabancı cisimlerin dağılımı.

\begin{tabular}{|c|c|c|}
\hline Hasta Sayısı & 64 & \\
\hline Yaş & $28.4(3-68)$ & \\
\hline \multirow{2}{*}{ cinsiyet } & Kadın & $30(\% 46,9)$ \\
\hline & Erkek & $34(\% 53,1)$ \\
\hline \multirow[t]{2}{*}{ Taraf } & Sağ & $37(\% 57,8)$ \\
\hline & Sol & $27(\% 42,2)$ \\
\hline \multirow{2}{*}{$\begin{array}{l}\text { Ekstremitedeki } \\
\text { seviyesi }\end{array}$} & Ayak bileği altı & $44(\% 68,8)$ \\
\hline & Ayak bileği üstü & $20(\% 31,2)$ \\
\hline \multirow{5}{*}{$\begin{array}{l}\text { Yabancı cisim } \\
\text { dağılımı }\end{array}$} & Metal iğne & $37(\% 57,9)$ \\
\hline & Cam & $7(\% 10,9)$ \\
\hline & Metal & $10(\% 15,6)$ \\
\hline & Ateşli Silah & $8(\% 12,5)$ \\
\hline & Tahta & $2(\% 3,1)$ \\
\hline \multirow{3}{*}{ Anestezi şekli } & Lokal & $42(\% 65,6)$ \\
\hline & Genel & $14(\% 21,9)$ \\
\hline & Rejyonel & $8(\% 12,5)$ \\
\hline
\end{tabular}

Tüm hastalara cerrahi öncesi $50 \mathrm{mg} / \mathrm{kg}$ profilaktik sefazolin sodyum verildi. Tetanoz profilaksisi ise acil klinikte şahsın bağışıklık durumuna göre yapıldı. Lokal anestezi ile cerrahi yapılan hastalar aynı gün, rejyonel ve genel anestezi yapilan hastalar ise cerrahi sonrası birinci günde taburcu edildi. Hastalarda herhangi bir komplikasyon gözlenmedi.

\section{TARTIŞMA}

Ekstremitelerde yumuşak doku yabancı cisim batmaları sık görülmesine rağmen bu konuda literatürde yeterli sayıda araştırma olmadığından yumuşak doku yabancı cisim yaralanmalarında standart tanı ve tedavi protokolleri net değildir ${ }^{1}$. 
Yabancı cisimler yumuşak dokuda ağrı, allerjik ve toksik reaksiyonlar, tümör benzeri oluşumlar, inflamasyon, enfeksiyon, vasküler oklüzyon, erozyon ve trombüs oluşumuna neden olabilirler. Keskin uçlu cisimler doku içinde ilerleyerek tendon ve nörovasküler yaralanmalarına neden olabilirler. Eklemlerle veya kemikle yerleşimlerinde ise septik artrit veya osteomyelite neden olabilirler ${ }^{2-5}$.

Yumuşak doku yabancı cisimlerinin tanısında iyi bir klinik muayene ve radyolojik değerlendirme çok önemlidir. Hastanın öyküsü ile yabancı maddenin niteliği tahmin edilerek ona yönelik tanı ve tedavi uygulamaları yapılabilir. Tanıda direkt radyografiler, ultrasonografi, bilgisayarlı tomografi ve manyetik rezonans görüntüleme teknikleri kullanılabilir. Direk radyografiler düşük maliyetli, kolay uygulanabilen ve çoğu yabancı cismin tanısına yardımcı olan bir görüntüleme yöntemidir. İki yönlü çekilen bir direkt radyografi ile taş ve kum parçaları, 2 mm'den büyük cam parçaları, metaller, kemik parçaları, bazı plastik ve tahta parçaları görülebilir. Tahta gibi yabancı cisimlerin sadece \%15'inde direkt radyografik görüntüleme ile tanı konulabilir. Normalde yumuşak dokuda radyolüsen bir görüntü veren tahta parçaları çok küçük değilse ilk 48 saat içinde radyografide görülebilir ancak sonrasında vücut sıvılarını emerek yoğunlukları çevre dokuların yoğunluklarına benzer olur ve direkt radyografilerde görülmemeye başlarlar. Eğer tahta parçaları kurşun ile kaplı ise 48 saat sonrasında da görülebilir ${ }^{6-9}$.

Bilgisayarlı tomografiler direkt radyografilerden daha üstündür ve daha fazla yabancı madde türünü tespit edebilirler. Düz radyografilerde görülmeyen bazı tahta ve diken parçaları bilgisayarlı tomografi ile görüntülenebilir ${ }^{10-13}$.

Direk radyografide görülemeyen non-opak yabancl cisimlerin tespitinde ultrasonografi geniş kabul gören, oldukça faydalı bir radyolojik tetkiktir. Ultrasonografi ile yabancı cisimlerin başarılı bir şekilde görüntülenmesi, nesnenin boyutuna, şekline, yönüne, bileşimine, görüntüleme sisteminin özelliklerine ve radyoloğun becerisine bağlıdır. Ultrasonografinin genel duyarlılığı \%50-90, özgüllüğü ise \%70-97 arasında değişmektedir ${ }^{14-19}$. Biz yabancı cisim batması nedeniyle acil servise başvuran tüm hastalarımıza tariflenen yabancı cismin tipine bakmaksızın standart ön-arka ve yan direk radyografi çekmekteyiz. Çalışmamızda direk radyografiyle hastalara \%96 oranında tanı konulmuştur. Direk radyografiler yabancı cismin tanısını koyarken aynı zamanda yabancı cismin lokalizasyonu ve tipi hakkında da bilgi vererek anestezi seçimini etkilemektedir. $\mathrm{Bu}$ nedenle yabancl cisim batma şikayeti olan tüm hastalara direk grafilerin çekilmesi gerektiğini düşünmekteyiz.

Alemdar ve ark.'nın (1) yaptıkları çalışmada opere ettikleri yabancl cisimlerin \%71 oranında alt ekstremitede gözlendiği bu hastaların \%41 oranında ise ayak bölgesindeki yabancl cisim nedeniyle opere edildiklerini belirtilmişlerdir. Bizim çalışmamızda da yabance cisimler \%59 oraninda olan alt ekstremite yaralanmalarının \%40,3'ünün ayak bölgesinde olduğu görülmüştür.

Her ne kadar ulaşılabilir tüm yabancı cisimlerin çıkartılması önerilse de bu durum tespit edilen yabancl cisimlerin tipi, tahmini boyutu, hayati organlara olan yakınlığı, vücutta verebileceği potansiyel inflamatuar ve toksik etkileri dikkate alınarak kâr zarar durumu göz önünde bulundurularak karar verilmelidir. Hiçbir belirtiye neden olmayan küçük, hareketsiz, derin yerleşimli nesneler genellikle yerinde bırakılabilir. Ateşli silah yaralanmasına bağlı mermi çekirdekleri genellikle çıkarılmaz çünkü yaplacak bir operasyon ekstra zararlara neden olabilir. Ancak, mermi çekirdekleri cilde yakın veya cildi irrite ediyorsa çıkarılmalıdır. Unutulmamalıdır ki mermi çekirdekleri veya parçacıkları bir parça kıyafet veya deriyi 
yumuşak doku içine sürükleyerek geç dönemde enfeksiyonlara neden olabilir. Özellikle yakın atışla oluşan ateşli silah yaralanmalarında dikkat edilmesi gereken noktalardan biride metalik saçma tanelerini bir arada tutan plastik kutununda vücuda girebilmesidir. Opere ettiğimiz hastalardan bir tanesinde bu plastik kutu vücut içinde tespit edilmiş ve çıkarılmıştır. $\mathrm{Bu}$ nedenle yakın atışlı av tüfeği yaralanmalarında saçma taneleriyle birlikte direk grafilerde görünmeyen bu plastiğk yapının yumuşak doku içinde olabileceği akılda tutulmalıdır.

Bitkisel yabancı cisimler yoğun ve aşırı enflamasyona neden olurlar, bu nedenle bunların hemen çıkarılması önerilmektedir. Yoğun bir şekilde kirlenmiş yabancı cisimler mümkün olan en kısa zamanda çıkartılmalıdır. Cam, metal ve plastik parçaları kısmi olarak hareketsiz ve nispeten inaktif oldukları için çıkarılmaları ertelenebilir. Tendon, nörovasküler dokular veya hayati organlara yakın olan iğne gibi sivri uçlu yabancı cisimler çıkarılmalıdır. Pürüz içermeyen, gözeneksiz yüzeylere sahip cisimler, pürüzlü yüzeylere göre daha az enflamasyon ve fibrozis üretirler. $\mathrm{Bu}$ enflamasyon ve fibrozis neticesinde yabancı cisim bir kist içerisinde kapsülle çevrilerek kapsül içine hapsedebilir. Alıkonan yabancı cisim etrafında kapsülleşme oluştuktan sonra, enflamatuar reaksiyon azalır. Bir kitle şekline dönüşen yabancı cisim klinik muayenede tümöral oluşum olarak karıştırılabilir 8,20-25.

Çocuklarda yabancı cisim giriş deliği kısa sürede kapanabilir ve yabanci cisim burada uzun süre sessiz kalabilir. Bu durumda hastanın kliniği ve öyküsü tanıda yardımcı olur. Ancak bazen bunlar yetersiz kalarak tespit edilemeyen yabancı cisimler yumuşak doku veya kemik üzerinde enfeksiyon gibi ikincil etkileri ortaya çıtıktan sonra fark edilebilir $3,8,26$.

Ayakkabıya veya çoraplı ayağa batan çivi gibi yabancı cisimler ayakkabı veya kumaş parçalarını ciltten geçirerek yumuşak doku içerisine inoküle edebilir. Yarada palpasyonda ağrı hissi veya yara içerisinde hasta tarafından hissedilen yabancı cisim hissi ciddiye alınarak ileri tetkik ve cerrahi uygulamalar düşünülmelidir ${ }^{20,27,28}$. Çalışmamızda hastaların $\% 2,7$ sinde yabancl cisim batma hikayesi olan ancak direk grafilerde görülmeyen hastaların yapılan cerrahisinde çok küçük cam parçaları çıkarıldı. Bu hastalarda en belirgin şikâyet içerde yabancı cisim olduğu hissiydi. Biz bu hastalara direk grafi dışında herhangi bir tetkik istemeden cerrahiye aldık. Bu hastalara direk grafi dışında diğer görüntüleme tetkikleri istenebilir. Biz bu hastalarda hastanın içerde yabancı cisim varlığını hissetmesinin tanıda önemli bir yerinin olduğunu ve bu hastalara cerrahi yapılması gerektiğine inanıyoruz

Yumuşak doku yabancı cisimlerinin çıkarılması acilde veya ameliyathanede yapılabilmekle birlikte, tüm cerrahi ișlemlerde sterilizasyon kurallarına uyulması enfeksiyonlardan korunmada önemlidir. Ayrıca, C-kollu floroskopi kontrolünde yapılan müdahaleler başarı için önemli kriterlerdir ${ }^{29}$.

Anestezi yöntemi olarak lokal anestezi, rejyonel anestezi ve genel anestezi kullanılabilir. Anestezi yönteminin seçimini hastanın yaşı, yabancı cismin lokalizasyonu ve tipi belirlemektedir. Çoğu yabancl cisim çlkarılmasında lokal anestezi yeterli olabilmektedir. Çocuk hastalarda lokal anestezi çocuk hastaların kooperasyon açısından uygun olmadığı için sıklıkla genel anestezi tercih edilmektedir. Erişkin hastalarda yüzeyel cisimlerin çıkarılması lokal anestezi ile mümkün olabilirken eklem içi ve kemik çevresi gibi derin yerleşimli yabancı cisimlerde ise rejyonel ve genel anestezi yöntemleri kullanılmaktadır ${ }^{30}$. Bizim çalışmamızda yetişkin hastaların \%82,6 oranında lokal ve rejyonel anestezi ile opere edilirken \%17,4 oranında genel anestezi ile opere edildikleri görüldü. Pediatrik yaş grubunda ise hastaların $\% 38,9$ oranında lokal anestezi ile opere 
edilirken \%61,1 genel anestezi ile opere edildikleri görüldü. Genel anestezi alan hastaların tümünde açlık süresinin beklenerek elektif şartlarda opere edildiği görüldü. Biz genel olarak ekstremite yabancl cisimlerinin genel anestezi altında alınması gerekiyorsa açlık süresine dikkat edilerek cerrahiye alınmasını önermekteyiz. Çocuk hastalarda lokal anesteziyle müdahale edilecekse dahi açlık süresinin genel anesteziye uygun olarak hazırlanması gerektiğini düşünmekteyiz.

Sonuç olarak, yabancı cisimlerinde iyi bir öykü ile birlikte direkt radyografi mutlak surette istenerek değerlendirilmelidir. Direkt radyografilerde görüntülenemeyen radyolusen yabancı cisim şüphesi durumlarında ultrasonografi ile tanıya ulaşma amaçlanmalı, tanıda halen şüphe varsa manyetik rezonans görüntüleme gibi ileri tetkikler yapılmalıdır. Lokal anestezi yabancı cismin çıkarılmasında çoğunlukla yeterli olmasına rağmen özellikle çocuk ve derin yerleşimli hastalarda diğer anestezi uygulamaları düşünülmelidir.

\section{Çıkar Çatışması Beyanı: Yazarlar çıkarçatışması olmadığını bildirmişlerdir.}

Finansal Destek: Bu çalışma her hangi bir fon tarafından desteklenmemiştir.

Declaration of Conflicting Interests: The authors declare that they have no conflict of interest.

Financial Disclosure: No financial support was received.

\section{KAYNAKLAR}

1. Alemdar C, Demirtaş A, Gem M, et al. Orthopedic approach to foreign body stings. J Clin Exp Invest. 2013; 4: 443-48.

2. Callegari L, Leonardi A, Bini A, et al. Ultrasound-guided removal of foreign bodies: personal experience. Eur Radiol. 2009; 10: 1273-79.
3. Divesh G, Agarwal A. Önkolda ağaç yabancı cisim: Sekiz yll sonraki başvuru. Ulus Travma Acil Cerrahi Derg. 2010; 16: 373-75.

4. Dadsetan MR, Jinkins JR. Peripheral vascular gunshot bullet embolus migration to the cerebral circulation. Neuroradiology. 1990; 32: 516-19.

5. Ando A, Hatori M, Hagiwara $Y$, Isefuku S, Itoi E. Imaging features of foreign body granuloma in the lower extremities mimicking a soft tissue neoplasm. Ups J Med sci. 2009; 114: 46-51.

6. Peterson JJ, Bancroft LW, Kransdorf MJ. Wooden foreign bodies: imaging appearance. AJR Am J Roentgenol. 2002; 178: 557-62.

7. Anderson MA, Newmeyer WL, Kilgore ES. Diagnosis and treatment of retained foreign bodies in the hand. Am J Surg. 1982; 144: 63-67.

8. Lammers RL. Soft tissue foreign bodies. Ann Emerg Med. 1988; 17: 1336-47.

9. Jaworsky C. Analysis of cutaneous foreign bodies. Clin Dermatol. 1991; 9: 157-78.

10. Bauer AR Jr, Yutani D. Computed tomographic localization of wooden foreign bodies in children's extremities. Arch Surg. 1983; 118: 1084-86.

11. Kjhns LR, Borlaza GS, Seigel RS, Paramagul C, Berger PE. An in vitro comparison of computed tomography, xeroradiography, and radiography in the detection of soft-tissue foreign bodies. Radiology. 1979; 132: 21819.

12. Rhoades CE, Soye I, Levine E, Reckling FW. Detection of a wooden foreign body in the hand using computed tomography--case report. J Hand Surg Am. 1982; 7: 306-7.

13. Yang XJ, Xing GF, Shi CW, Li W. Value of 3dimensional CT virtual anatomy imaging in complex foreign body retrieval from soft tissues. Korean J Radiol. 2013; 14: 269-77.

14. Graham DD Jr. Ultrasound in the emergency department: detection of wooden foreign bodies in the soft tissues. The Emerg Med. 2002; 22: 75-79.

15. Jacobson JA, Powell A, Craig JG, Bouffard JA, van Holsbeeck MT. Wooden foreign bodies in soft tissue: detection at US. Radiology. 1998; 206: 45-48.

16. Manthey DE, Storrow AB, Milbourn JM, Wagner BJ. Ultrasound versus radiography in the detection of softtissue foreign bodies. Ann Emerg Med. 1996; 28: 7-9. 
17. Hill R, Conron R, Greissinger P, Heller M. Ultrasound for the detection of foreign bodies in human tissue. Ann Emerg Med. 1997; 29: 353-56.

18. De Flaviis L, Scaglione P, Del Bò P, Nessi R. Detection of foreign bodies in soft tissues: experimental comparison of ultrasonography and xeroradiography. J Trauma. 1988; 28: 400-4.

19. Gilbert FJ, Campbell RS, Bayliss AP. The role of ultrasound in the detection of non-radiopaque foreign bodies. Clin Radiol. 1990; 4: 109-12.

20. Capellan O, Hollander JE. Management of lacerations in the emergency department. Emerg Med Clin North Am. 2003; 21: 205-31.

21. Hirsh BC, Johnson WC. "Pathology of granulomatous diseases: foreign body granulomas. Int J Dermatol. 1984; 23: 531-38.

22. Snyder RA, Schwartz RA. Cactus bristle implantation: Report of an unusual case initially seen with rows of yellow hairs. Arch Derrmatol. 1983; 119: 152-54.

23. Smoot EC, Robson MC. Acute management of foreign body injuries of the hand. Ann Emerg Med. 1983; 12: 434-37.
24. London PS. Wounds of deep significance: unsuspected foreign bodies in wounds. Injury. 1972; 3: 179-80.

25. Swischuk LE, Jorgenson F, Jorgenson A, Capen D. Wooden splinter induced" pseudotumors" and" osteomyelitis-like lesions" of bone and soft tissue. Am J Roentgenol Radium Ther Nucl Med. 1974; 122: 176-79.

26. Johnson DG, Condon VR. Foreign bodies in the pediatric patient. Curr Probl Surg. 1998; 35: 271-79.

27. Montano JB, Steele MT, Watson WA. Foreign body retention in glass-caused wounds. Ann Emerg Med. 1992; 21: 1360-63.

28. Steele MT, Tran LV, Watson WA, Muelleman RL. Retained glass foreign bodies in wounds: predictive value of wound characteristics, patient perception, and wound exploration. Am J Emerg Med. 1998; 16: 627-30.

29. Yıldırım C, Sözüer EM, Avşaroğlulları L, Karaoğlu S, Günay N. Yumuşak Doku İçindeki Radyoopak Yabancı Cisimlerin Stereotaksik Yöntemle Çıkarılması. Ulus Travma Acil Cerrahi Derg. 1999; 5: 213-16.

30. Hocaoğlu E, Kuvat SV, Özalp B, et all. Foreign body penetrations of hand and wrist: a retrospective study. Ulus Travma Acil Cerrahi Derg. 2013; 19: 58-64. 